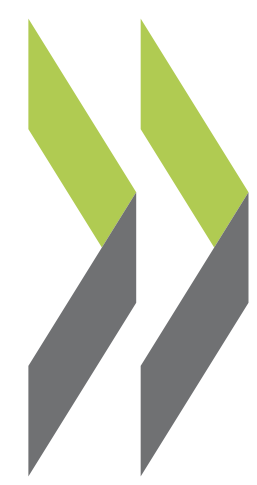

OECD Economics Department Working Papers No. 1617

Services trade costs in the United States: A simulation based

on the OECD Services

Trade Restrictiveness Index
Sebastian Benz,

Alexander Jaax 


\section{ECONOMICS DEPARTMENT}

\section{SERVICES TRADE COSTS IN THE UNITED STATES: A SIMULATION BASED ON THE OECD SERVICES TRADE RESTRICTIVENESS INDEX}

\section{ECONOMICS DEPARTMENT WORKING PAPERS No.1617}

By Sebastian Benz and Alexander Jaax

OECD Working Papers should not be reported as representing the official views of the OECD or of its member countries. The opinions expressed and arguments employed are those of the author(s).

Authorised for publication by Isabell Koske, Deputy Director, Country Studies Branch, Economics Department.

All Economics Department Working Papers are available at www.oecd.org/eco/workingpapers.

JT03465023 
OECD Working Papers should not be reported as representing the official views of the OECD or of its member countries. The opinions expressed and arguments employed are those of the author(s).

Working Papers describe preliminary results or research in progress by the author(s) and are published to stimulate discussion on a broad range of issues on which the OECD works.

Comments on Working Papers are welcomed, and may be sent to the Economics Department, OECD, 2 rue André-Pascal, 75775 Paris Cedex 16, France, or by e-mail to eco.contact@oecd.org.

All Economics Department Working Papers are available at www.oecd.org/eco/workingpapers.

This document and any map included herein are without prejudice to the status of or sovereignty over any territory, to the delimitation of international frontiers and boundaries and to the name of any territory, city or area.

The statistical data for Israel are supplied by and under the responsibility of the relevant Israeli authorities. The use of such data by the OECD is without prejudice to the status of the Golan Heights, East Jerusalem and Israeli settlements in the West Bank under the terms of international law.

\section{(C) OECD (2020)}

You can copy, download or print OECD content for your own use, and you can include excerpts from OECD publications, databases and multimedia products in your own documents, presentations, blogs, websites and teaching materials, provided that suitable acknowledgment of OECD as source and copyright owner is given. All requests for commercial use and translation rights should be submitted to rights@oecd.org 


\section{Abstract / Resumé \\ Services trade costs in the United States: A simulation based on the OECD Services Trade Restrictiveness Index}

While services account for almost $80 \%$ of GDP in the United States and a growing share of global trade, regulatory barriers to services trade around the world are still high. Using a hypothetical liberalisation scenario, this paper assesses the potential reduction of trade costs that could be achieved in 17 US services sectors. The analysis relies on the OECD Services Trade Restrictiveness Index (STRI) which records barriers to services trade in 46 economies. The illustrative scenario assumes a $50 \%$ reduction in the gap between the current STRI score of the United States and the score of the least restrictive country in each sector. The results highlight the economic benefits of aligning US services regulation with global best practice. The average reduction in trade costs across the 17 sectors analysed would amount to 9.7 percentage points, with a quarter of the sectors experiencing reductions larger than 14.1 percentage points and another quarter experiencing reductions smaller than 5.3 percentage points.

JEL classification: F13, F14, F15, F68, L88

Key words: Services trade, trade cost, trade liberalisation, services trade restrictions, regulation

This Working Paper relates to the 2020 OECD Economic Survey of the United States

(www.oecd.org/economy/united-states-economic-snapshot/).

$* * * * * * * * * * * * * * * * * * * * * * * * * * * * * *$

\section{Les coûts des échanges de services aux États-Unis : simulation fondée sur l'Indice de restrictivité des échanges de services établi par l'OCDE}

Les services représentent près de $80 \%$ du PIB des États-Unis et une part croissante des échanges mondiaux ; pourtant, les obstacles réglementaires aux échanges de services restent importants partout dans le monde. À partir d'un scénario de libéralisation théorique, la présente étude livre une évaluation de la baisse des coûts des échanges dont pourraient bénéficier 17 secteurs de services aux États-Unis. Cette analyse se fonde sur l'Indice de restrictivité des échanges de services (IRES) établi par l'OCDE, qui recense les obstacles aux échanges de services dans 46 pays. Le scénario présenté à titre indicatif prévoit une réduction de moitié de l'écart entre la valeur actuelle de l'IRES pour les États-Unis et celle du pays le moins restrictif dans chaque secteur. Les résultats mettent en lumière tout l'intérêt, sur le plan économique, d'aligner la réglementation américaine en matière de service sur les meilleures pratiques mondiales. En moyenne, la baisse des coûts des services dans les 17 secteurs étudiés s'élèverait à 9.7 points de pourcentage, sachant qu'un quart des secteurs bénéficieraient d'une baisse des coûts supérieure à 14.1 points et que pour un autre quart des secteurs, la baisse serait inférieure à 5.3 points.

Codes JEL : F13, F14, F15, F68, L88

Mots clés : échanges de services, coûts des services, libéralisation des échanges, restrictions aux échanges de services, réglementation.

Le présent document de travail concerne l'Étude économique 2020 des États-Unis

(www.oecd.org/fr/economie/etats-unis-en-un-coup-d-oeil/). 


\section{Table of contents}

Services trade costs in the United States: A simulation based on the OECD Services

Trade Restrictiveness Index

Introduction

Measuring non-tariff barriers in services

Estimation Strategy

Data

Regression Results

Annex A.

Sector Correspondence

Tables

Table 1. Results of gravity regressions

Table 2. United States has scope for substantial reduction of services barriers

Table 3. Elasticities of substitution

Table 4. Substantial reduction of services trade costs are possible

Figures

Figure 1. STRI by sector and policy area in the United States, 2019 


\title{
Services trade costs in the United States: A simulation based on the OECD Services Trade Restrictiveness Index
}

\author{
By Sebastian Benz and Alexander Jaax ${ }^{1}$
}

\section{Introduction}

1. Services account for more than two-thirds of GDP in advanced economies, and for almost $80 \%$ of GDP and employment in the United States. At the same time, services contribute $52 \%$ of the value of the United States' gross exports and nearly $70 \%$ of exports in value added terms, indicating that exports of goods rely intensively on services inputs. There is increasing awareness of the importance of services as key inputs to manufacturing activities in global value chains (GVCs) (Miroudot and Cadestin, 2017; Andrenelli et al., 2018) and the local availability of business services has been shown to improve the capacity of manufacturing firms to enter foreign markets (Görg and Jabbour, 2016) and source inputs from abroad (Debaere, Görg, Raff, 2013). There is also a growing recognition that dismantling barriers to trade in services offers opportunities to exploit untapped economic potential. However, the difficulty in quantifying the costs of regulatory restrictions on trade in services has often hampered efforts to analyse the economic effects of services trade liberalisation.

2. Focusing on cross-border services trade, this paper assesses the potential reduction in trade costs that could be achieved in 17 US services sectors ${ }^{2}$. The paper highlights the economic benefits of narrowing

\footnotetext{
${ }^{1}$ Sebastian Benz (sebastian.benz@oecd.orgmailto:) and Alexander Jaax (alexander.jaax@oecd.org) are members of the OECD Trade and Agriculture Directorate. They would like to thank Douglas Sutherland, Annabelle Mourougane, John Drummond, Jehan Sauvage, and Ben Westmore (all from the OECD) for helpful suggestions. The paper has also benefitted from comments provided by members of the OECD Economic and Development Review Committee. The authors also thank Stephanie Henry for preparing this paper for publication.

2 Throughout this paper, "cross-border services trade" is used according to the Manual on Statistics of International Trade in Services (MSITS) 2010, referring to the value of services trade measured in the balance of payments, covering all services transactions between residents and non-residents. This definition is broader than the definition of cross-border services trade (Mode 1) in the GATS, which only covers transactions "from the territory of one Member into the territory of any other Member". In general, service transactions between residents and non-residents, as captured in the balance of payments, broadly cover Modes 1, 2 and 4 (United Nations, 2012). The four modes of
} 


\section{6 | ECO/WKP(2020)25}

the gap between current US services regulation and global best practice. The results are not only interesting in and of themselves, but they can also be used as input for further analysis in computable general equilibrium (CGE) models. The analysis relies on the OECD Services Trade Restrictiveness Index (STRI), a database of barriers to services trade in 46 economies and 22 sectors, covering the years 2014 to 2019 and on estimates of ad valorem equivalents for cross-border services trade based on the OECD STRI developed in a gravity framework by Benz and Jaax (2020).

3. The illustrative service trade liberalisation scenario considered in this paper assumes in a given sector a $50 \%$ reduction in the gap between the current STRI score for the United States and the score of the least restrictive country, amongst those covered by the OECD STRI dataset. This hypothetical scenario would be considered ambitious in some sectors, such as air transport. It only reflects a minor services liberalisation in other sectors, such as rail transport, road freight transport or telecommunications where the current US regime is already very close to that of the OECD best performer.

4. The purpose of this scenario is to provide insights on the potential gains from regulatory changes in the US services sectors. Given this objective, we do not discuss the political feasibility of such a reform - this would be beyond the scope of this paper. We therefore focus on the quantification of trade cost changes in an illustrative scenario. Whilst we do not discuss specific reform proposals, the scenario described in this paper can serve as inspiration and provide guidance regarding the debate about services regulation in the United States.

5. Overall, such a hypothetical liberalisation could lead to a substantial decrease in policy-induced trade costs for services. The mean reduction in trade costs for the 17 sectors analysed would amount to 9.7 percentage points, with a quarter of the sectors experiencing reductions greater than 14.1 percentage points and another quarter experiencing reductions smaller than 5.3 percentage points. Trade costs would be reduced by roughly a fifth in air transport, courier services, and insurance.

\section{Measuring non-tariff barriers in services}

6. The OECD Services Trade Restrictiveness Index (STRI) is derived from a database of qualitative information on trade policy measures, using a codified algorithm for scoring and weighting. It measures the restrictiveness of services trade barriers on a scale from zero to one, with zero being most liberal and one being most restrictive. Existing estimates show that these barriers are important determinants of global cross-border services trade patterns, but they also have an impact on downstream manufacturing sectors (Benz, 2017; Nordås and Rouzet, 2017; Rouzet, Benz and Spinelli, 2017). Updated on an annual basis, the STRI currently covers 46 countries, 22 sectors and six years (2014-2019) ${ }^{3}$.

7. Most services trade policies apply multilaterally to all trading partners. To some extent, this is because services barriers include behind-the-border measures related to the domestic regulatory regime, applying to domestic as well as all foreign services providers. For this reason, the STRI is a measure of Most Favoured Nations (MFN) restrictions and does not take into account bilateral deals such as regional

services trade according to the General Agreement on Trade in Services (GATS) are cross-border trade (Mode 1), consumption abroad (Mode 2), commercial presence (Mode 3), and temporary movement of natural persons (Mode 4).

${ }^{3}$ It stands in the tradition of earlier work by the Australian Productivity Commission, which made a first attempt at cataloguing and quantifying services trade restrictions across countries and sectors in the mid-1990s (Findlay and Warren, 1990). Some years later, the World Bank published information on policies that affect international trade in services in 103 countries and five broad sectors for the year 2008 (Borchert, Gootiiz and Mattoo, 2013). 
trade agreements or mutual recognition agreements (Geloso Grosso et al., 2015). ${ }^{4}$ This has a negligible effect on the measurement of services restrictiveness, since preferential liberalisation of the applied regimes in regional trade agreements (RTAs) is not common (Lamprecht and Miroudot, 2018). The only exception is the European Economic Area (EEA). Services liberalisation within the Single Market of the EEA is measured in the intra-EEA STRI (Benz and Gonzales, 2019).

8. The United States' score on the STRI in the 17 sectors included in the simulations presented in this paper is shown in Figure 1, along with the average and the lowest score among the 46 countries included in the STRI database for each sector. The STRI score of the United States is lower than the cross-country average in 13 out of the 17 sectors included in the analysis. Accounting services, legal services, and rail freight transport services are the three sectors in the United States with the lowest score relative to the average across all countries covered by the STRI database ${ }^{5}$. Conversely, maritime transport, courier services, and air transport services are the three sectors with the highest score in the United States relative to the average across the countries included in the database.

Figure 1. STRI by sector and policy area in the United States, 2019

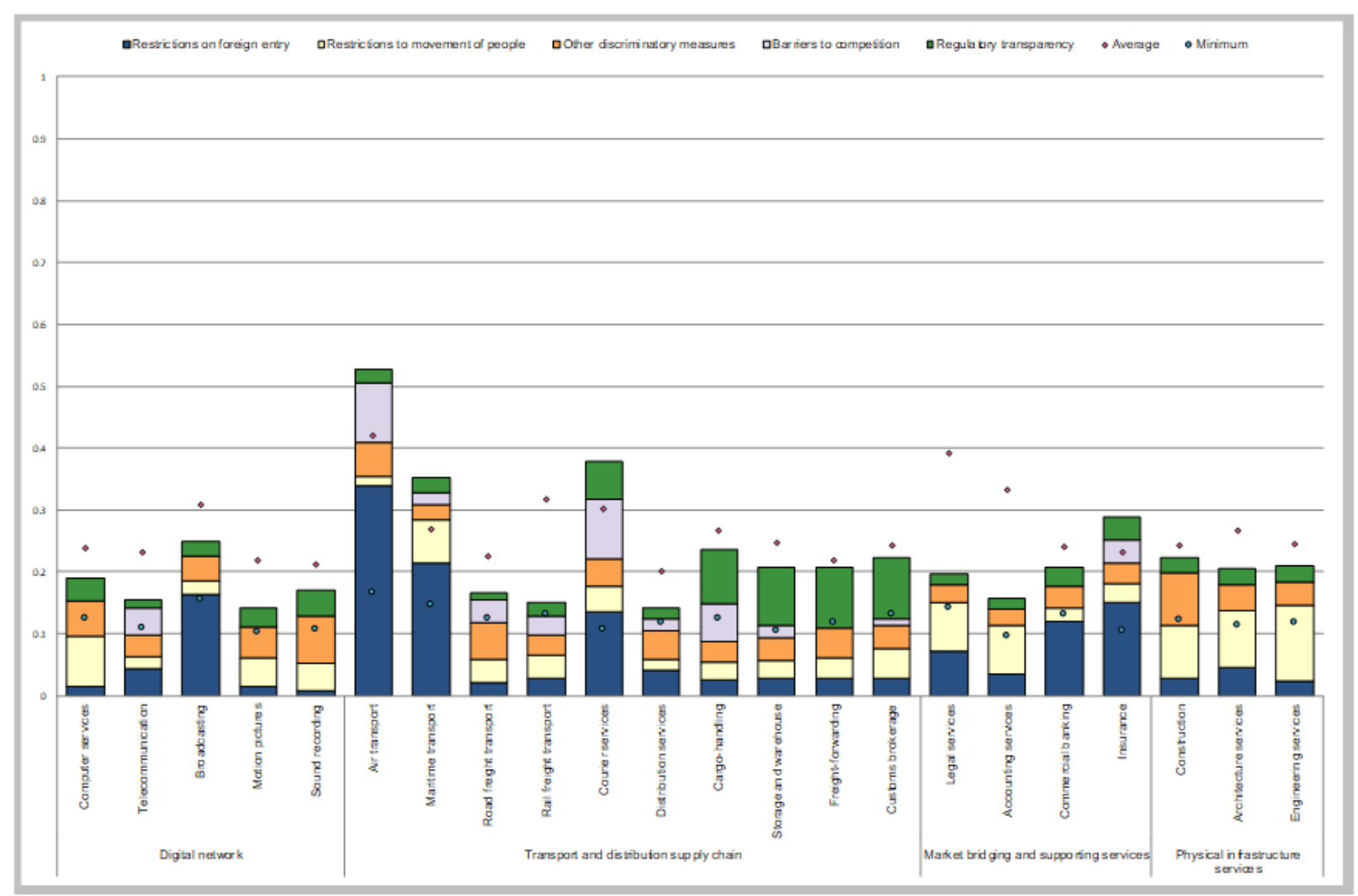

Note: The STRI indices take values between zero and one, one being the most restrictive. Source: OECD STRI database.

\footnotetext{
4 The United States currently is party to 14 regional trade agreements with 20 partner countries, including the OECD Members Australia, Canada, Colombia, Japan, Korea and Mexico.

${ }^{5}$ In accounting services, which covers also auditing services, the managers of a professional service corporation must be licensed professionals. Furthermore, foreigners seeking to provide services in either profession must pass a competence exam and fulfil a practice requirement for at least one year. Professional services are regulated at the state level; the STRI considers New York state regulations. Legal practice is open to foreign qualified professionals who pass the local bar exam. Rail freight has a liberal regime for foreign investment and access rights are granted for international rail transport, except for the domestic legs.
} 


\section{Estimation Strategy}

9. The empirical strategy employed to convert the information in the STRI database into AVEs is based on a gravity model, the workhorse model of the empirical trade literature. Traditionally used primarily to analyse patterns of trade in goods, gravity equations have also been widely applied to cross-border trade in services (Eaton and Kortum, 2018; Nordås and Rouzet, 2017; Van der Marel and Shepherd, 2013; Anderson et al., 2015). Formally, the gravity model can be expressed as follows:

$$
\text { Exports }_{i j}=\frac{G D P_{i} G D P_{j}}{G D P_{\text {world }}}\left(\frac{\text { tradecost }_{i j}}{\Pi_{i} P_{j}}\right)^{(1-\sigma)}
$$

where the left-hand side variable represents the trade flow from exporter $i$ to importer $j$. The second term ensures that the model takes into account GDP proportionality, whereas the third term captures the role of trade costs which encompass two main components: First, pair-specific costs of economic transactions between two countries $i$ and $j$. Second, the above-mentioned country-specific costs of engaging in trade with the rest of the world, here represented by $\Pi i$ and $P j$. The parameter $\sigma$ is the elasticity of substitution between foreign and domestic goods and services.

10. This model remains valid when $i$ and $j$ reference the same country. In this case, the variable tradecost $i j$ indicates internal trade costs within a country, while $\Pi i$ and $P j$ are defined as above and now indicate inward multilateral resistance and outward multilateral resistance of the same country ${ }^{6}$. In the econometric specification, internal trade costs within a country are captured by fixed effects and the STRI measures the difference between political barriers to international cross-border services trade and political barriers to domestic services consumption.

11. Calculated as the share of gross production that is not exported, the addition of a country's trade with itself aligns the gravity estimations with the modelling of choices between domestic and foreign goods (Yotov et al., 2016; Dai, Yotov and Zylkin, 2014; Yotov, 2012). Moreover, the inclusion of within-country trade permits to analyse the effect of multilateral policy variables, i.e. variables that do not vary bilaterally, without omitting multilateral resistance terms (Heid, Larch and Yotov, 2015).

12. The gravity estimations presented in this paper are run separately for each sector and estimated using the Poisson Pseudo Maximum Likelihood (PPML) technique introduced by (Santos Silva and Tenreyro, 2006). This approach is now commonly used for the estimation of the gravity model. It is superior to the traditional log-linearized estimation with ordinary least squares, due to its robustness to different patterns of heteroscedasticity. Moreover, it allows retaining zeros in bilateral trade data, which would otherwise get lost in the logarithmic transformation of the model.

13. The regressions rely on variations of the following specification:

$$
\text { exports }_{i j, k}=\exp \left(\beta_{1} S T R I_{j, k} \text { border }_{i j}+\beta_{2} \text { border }_{i j}+\gamma Z_{i j}+\eta_{i, k}+\mu_{j, k}+\varepsilon_{i j, k}\right)
$$

where the dependent variable are services exports from country $i$ to country $j$ in sector $k$ measured in million USD. Exporter and importer fixed effects $\eta_{-}(i, k)$ and $\mu_{-}(j, k)$ control for multilateral resistance terms and all other country-specific variables. A set of standard gravity variables (represented by $Z$ ) control for other determinants of bilateral trade costs. A dummy variable border_(ij) is equal to zero when $i$ and $j$ refer to the same country so that exports_(ij,k) indicates the value of domestic production consumed domestically. The dummy variable is equal to one when $i$ and $j$ refer to different countries. $\beta_{-} 1$ is the main

\footnotetext{
${ }^{6}$ With symmetric trade barriers, theoretical inward and outward multilateral resistance are identical (Anderson and Van Wincoop, 2003).
} 
coefficient of interest; it represents the effect of changes in the STRI score of the importer $j$ on the estimated flow of services exports from country $i$ to country $j$ relative to domestic services consumption in country $j$. In other words, the resulting coefficient demonstrates the existence of policy-induced trade costs if a higher STRI is correlated with less international trade relative to domestic services consumption. Standard errors are clustered by exporter and importer.

\section{Data}

14. Data on cross-border services trade come from the OECD International Trade in Services Statistics (ITSS), covering services trade for a large number of services categories based on the Extended Balance of Payments Services Classification (EBOPS) 2010 classification. As customary in the related literature (Benz, 2017; Nordås and Rouzet, 2017), information provided by a country's trade partners was used in those cases where the exporter provides insufficiently disaggregated data. This mirroring of trade flows allows for the inclusion of all major economies with large services exports and ensures that the analysis covers all 46 countries for which STRI data are available.

15. In those cases where the exporter is the same country as the importing country, the export variable corresponds to within-country trade, defined as the share of gross services production in the corresponding sector that is consumed domestically. Data for within-country trade are constructed by deducting a country's sector-level exports to the world (taken from the OECD EBOPS 2010 database) from gross production in that sector. Data on gross production mostly come from the OECD national accounts and STAN databases.

16. Data for standard gravity controls (distance, contiguity, common language, former colony, common legal system, and common religion) are provided by CEPII. The regressions also include dummy variables for membership in the same regional trade agreement (RTA). Data on RTA membership comes from the DESTA database (Dür, Baccini and Elsig, 2014). Moreover, a dummy equalling one if both trade partners are EEA members is included in order to control for the profound economic integration and institutional coordination among EEA member states.

\section{Regression Results}

17. The main specification of the gravity model exploits only cross-sectional variation of the data (Table 1). This is done by calculating average values of services exports over all years with available data and using each country's average STRI over this period. This approach mitigates potential measurement error and allows for straightforward comparison with existing studies. Estimates rely on differences across countries and trading partners at a given point in time. These differences do not only reflect different levels of services trade restrictiveness, but also differences in the business structure and networks of value chains. Consequently, the level of policy-induced trade costs derived from such cross-sectional variation must be interpreted as the potential for trade cost reduction in the long-run, after businesses have had time to make investments in tangible and intangible capital, establish new business contacts and adjust their production and sales networks.

18. For all sectors, more restrictive services trade regulation is associated with lower values of international services trade relative to domestic services consumption. The resulting coefficients range between -3.5 for transport services and -7.3 for financial services. All regression coefficients are highly significant at the $1 \%$ level.

19. Services liberalisation within the European Economic Area creates stronger trade linkages between members than with countries outside of this bloc. Using the intra-EEA STRI, this effect is captured 
by the STRI coefficient ${ }^{7}$. For example, in communications services, the average intra EEA STRI has a value of 0.06 , while the average MFN STRI of EEA members has a value of 0.19 . This indicates that EEA members trade $49 \%$ more with another EEA member than with a third country that is not in the EEA but has otherwise identical characteristics ${ }^{8}$.

20. Domestic services consumption is substantially higher than services imports in all sectors. The border dummy, which equals one if the corresponding observation refers to an international trade flow rather than the consumption of domestically produced services, is in all cases negative and strongly significant. The size of the coefficients on the border dummy indicates that services imports currently represent just between $1 \%$ and $3 \%$ of their potential level in the absence of all natural barriers, technological constraints and consumer preferences that lead to the consumption of domestic services rather than imported services. ${ }^{9}$

21. Most other regression coefficients are in line with the literature (Head and Mayer, 2014). Common language and bilateral geographic distance have the expected sign in all sectors and are highly significant. Geographic distance seems to be less important for trade in financial services. Contiguity is often insignificant, indicating that distance is a good indicator for geographic trade costs in most services sectors. Exceptions are transport, where countries trade more with their direct neighbours than with other countries, and communications services, where contiguity is negatively associated with the value of cross-border services trade.

22. The overall pattern emerging from this analysis continues to hold in several robustness checks (Benz and Jaax, 2020). The robustness checks include panel analysis with exporter-year and importeryear fixed effects, panel analysis with additional country pair fixed effects, cross-sectional analysis in individual years, replacing the intra-EEA STRI with each country's regular MFN STRI, excluding all intraEEA trade, omitting all intra-national trade flows and using OLS instead of the PPML estimator.

\footnotetext{
7 Given that the STRI variable corresponds to the intra-EEA STRI for flows between two EEA members, it is not surprising that the coefficient of the EEA dummy is not significant in most sectors: the relevant regulatory differences are captured by the STRI variable.

8 Using the coefficients for the STRI and the EEA dummy, this effect can be calculated as $\exp \left(4.403^{*}(0.19-0.06)\right.$ $0.173)-1=49 \%$.

${ }^{9}$ International trade in goods is closer to its frictionless trade potential, with estimates ranging between $7 \%$ and $56 \%$. Actual trade is smaller in sectors such as food, wood, paper and minerals and largest in the machinery sector (Heid, Larch and Yotov, 2015).
} 
Table 1. Results of gravity regressions

\begin{tabular}{|c|c|c|c|c|c|}
\hline & (1) & (2) & (3) & (4) & (5) \\
\hline Sector & Communication & Business & Finance & Insurance & Transport \\
\hline \multirow[t]{2}{*}{ Log distance } & $-0.737^{\star \star *}$ & $-0.584^{\star * *}$ & -0.170 & $-0.690^{\star * *}$ & $-0.360^{\star \star *}$ \\
\hline & $(0.103)$ & $(0.133)$ & $(0.315)$ & $(0.186)$ & $(0.094)$ \\
\hline \multirow[t]{2}{*}{ Contiguity } & $-0.257^{*}$ & 0.009 & 0.191 & -0.139 & $0.273^{* *}$ \\
\hline & $(0.126)$ & $(0.133)$ & $(0.338)$ & $(0.319)$ & $(0.115)$ \\
\hline \multirow[t]{2}{*}{ Common language } & $0.961^{* \star *}$ & $0.903^{\star * *}$ & $1.499^{* \star *}$ & $0.869^{* \star \star}$ & $0.703^{* * *}$ \\
\hline & $(0.229)$ & $(0.199)$ & $(0.168)$ & $(0.225)$ & $(0.110)$ \\
\hline \multirow[t]{2}{*}{ Previous colonial relationship } & $-0.251^{* *}$ & $-0.172^{*}$ & $0.458^{\star * *}$ & $0.458^{* *}$ & $0.600^{* * *}$ \\
\hline & $(0.099)$ & $(0.102)$ & $(0.134)$ & $(0.225)$ & $(0.171)$ \\
\hline \multirow[t]{2}{*}{ Common legal origin } & -0.086 & 0.011 & -0.215 & 0.076 & -0.028 \\
\hline & $(0.109)$ & $(0.117)$ & $(0.177)$ & $(0.170)$ & $(0.133)$ \\
\hline \multirow[t]{2}{*}{ Common religion } & 0.040 & -0.097 & 0.151 & -0.209 & 0.230 \\
\hline & $(0.306)$ & $(0.306)$ & (0.661) & $(0.548)$ & $(0.268)$ \\
\hline \multirow[t]{2}{*}{ RTA } & -0.035 & $-0.399^{* *}$ & -0.320 & $-0.594^{* *}$ & 0.012 \\
\hline & $(0.252)$ & $(0.162)$ & $(0.244)$ & $(0.252)$ & $(0.126)$ \\
\hline \multirow[t]{2}{*}{ EEA } & -0.332 & $-1.041^{* * *}$ & -0.106 & -0.202 & 0.006 \\
\hline & $(0.301)$ & $(0.371)$ & $(0.505)$ & $(0.541)$ & $(0.320)$ \\
\hline \multirow[t]{2}{*}{ International border } & $-3.674^{* * *}$ & $-4.256^{\star * *}$ & $-4.467^{\star * *}$ & $-4.063^{\star * *}$ & $-4.152^{\star \star \star}$ \\
\hline & $(0.315)$ & $(0.363)$ & $(0.705)$ & $(0.536)$ & $(0.331)$ \\
\hline \multirow[t]{2}{*}{ International border x STRI } & $-4.515^{\star \star *}$ & $-3.920^{* * *}$ & $-7.335^{\star * *}$ & $-5.002^{\star \star *}$ & $-3.543^{\star \star *}$ \\
\hline & (0.991) & $(1.372)$ & (1.608) & $(0.957)$ & $(1.039)$ \\
\hline \multirow[t]{2}{*}{ Constant } & $17.916^{* * *}$ & $18.225^{\star * *}$ & $13.952^{* * *}$ & $17.059^{* * *}$ & $14.803^{\star * *}$ \\
\hline & (0.731) & (0.951) & (2.207) & $(1.331)$ & (0.659) \\
\hline Observations & 1,549 & 1,518 & 1,343 & 1,294 & 1,436 \\
\hline Exporter F.E. & YES & YES & YES & YES & YES \\
\hline Importer F.E. & YES & YES & YES & YES & YES \\
\hline
\end{tabular}

Note: This table presents the results of gravity regressions that were run separately for each sector. They were estimated using the Poisson Pseudo Maximum Likelihood (PPML) technique and rely on cross-sectional variation. The coefficient of Border X STRI is the main coefficient of interest. It represents the effect of changes in the STRI score of the importer $j$ on the estimated flow of services exports from exporting country $i$ to country j relative to domestic services consumption in country j. Standard errors clustered by exporter and importer in parentheses ${ }^{* *} p<0.01,{ }^{* *} p<0.05,{ }^{*} p<0.1$. RTA indicates a bilateral regional trade agreement. EEA indicates simultaneous EEA membership of exporter and importer.

Source: Author's calculations.

\section{Simulation Design}

23. For the purpose of the simulation presented in this note, it is assumed that the United States manages to halve the gap between their own restrictiveness in the services sectors and the best performer. The corresponding changes in the STRI score are summarised in Table 2. On average, this is a moderately ambitious scenario with substantial heterogeneity across sectors. Interestingly, the United States is not the most liberal country in any of the 17 sectors.

24. Depending on the sector, this liberalisation represents only a minor reduction or a more substantial reduction in the STRI. On the one hand, in the rail freight transport sector, the difference between the United States and the best performer is just 0.022 . Consequently, the liberalisation scenario corresponds to a reduction by 0.011 , from 0.151 to 0.140 . On the other hand, services regulation in the US air transport sector is relatively restrictive. In fact, with its score of 0.527 it is three times more restrictive than the best performing country, Chile. Hence, this scenario corresponds to a reduction of the STRI score by 0.181 . 
Table 2. United States has scope for substantial reduction of services barriers

\begin{tabular}{l|r|r|r}
\hline \multicolumn{1}{|c|}{ Sector } & USA STRI & Best performer STRI & Simulated change in US STRI score \\
\hline Computer services & 0.189 & 0.123 & -0.033 \\
\hline Legal services & 0.196 & 0.141 & -0.027 \\
\hline Accounting services & 0.158 & 0.096 & -0.031 \\
\hline Architecture services & 0.204 & 0.113 & -0.046 \\
\hline Engineering services & 0.210 & 0.118 & -0.046 \\
\hline Telecommunication & 0.156 & 0.108 & -0.024 \\
\hline Commercial banking & 0.206 & 0.131 & -0.038 \\
\hline Insurance & 0.288 & 0.104 & -0.092 \\
\hline Air transport & 0.527 & 0.165 & -0.181 \\
\hline Maritime transport & 0.352 & 0.147 & -0.103 \\
\hline Road freight transport & 0.167 & 0.124 & -0.021 \\
\hline Rail freight transport & 0.151 & 0.129 & -0.011 \\
\hline Courier services & 0.378 & 0.106 & -0.136 \\
\hline Logistics cargo-handling & 0.235 & 0.125 & -0.055 \\
\hline Logistics storage and warehouse & 0.207 & 0.105 & -0.051 \\
\hline Logistics freight forwarding & 0.208 & 0.117 & -0.046 \\
\hline Logistics customs brokerage & 0.223 & 0.130 & -0.047 \\
\hline
\end{tabular}

Note: The scenario is based on the assumption of closing $50 \%$ of the gap between the current regime in the United States and the best performing country.

Source: Author's calculations based on OECD STRI database 2019: oe.cd/stri

25. Converting the coefficients obtained from the regressions presented in Table 1 into trade cost equivalents requires information on the elasticity of substitution between varieties of traded services. Commonly, this elasticity is referred to as sigma. This analysis relies on the simple average of five different estimates of sigma reported in the recent empirical services trade literature. Table 2 summarises all elasticities and their respective sources.

26. The calculation of trade cost effects uses the following formula for changes in the ad valorem trade cost equivalent in sector $\mathrm{k}$. In this formula, exp is an exponential function, $\beta \_k$ is the point estimate for the STRI reported in Table 1 and $\sigma \_k$ is the average elasticity of substitution reported in Table 2. The equation expresses the relative change in trade costs due to a change in the level of the STRI from $S T R I k^{\wedge}$ current to STRI_k$k^{\wedge}$ simulated. In addition to the point estimate $\beta \_k$ it is possible to use information on the standard error of the regression coefficient in order to calculate a confidence interval for the trade cost effect.

$$
\widehat{A V E_{k}}=\frac{\text { tradecost }_{k}^{\text {simulated }}}{\text { tradecost }_{k}^{\text {current }}}=\exp \left(-\frac{\left(S T R I_{k}^{\text {current }}-S T R I_{k}^{\text {simulated }}\right) * \beta_{k}}{\left(\sigma_{k}-1\right)}\right)-1
$$

Since the ad valorem equivalent is equal to one in the absence of trade costs, the indicated effect is quantitatively similar to a reduction of trade costs in percentage points. 
Table 3. Elasticities of substitution

\begin{tabular}{|c|c|c|c|c|c|c|}
\hline Sector & $\begin{array}{l}\text { Rouzet, Benz } \\
\text { and Spinelli } \\
(2017)\end{array}$ & $\begin{array}{l}\text { Egger et } \\
\text { al. (2020) }\end{array}$ & $\begin{array}{c}\text { Fontagné, Orefice and Santoni } \\
\text { (2019) (Fontagné, Orefice and } \\
\text { Santoni, 2019 } \\
{\left[{ }_{[1]}\right)}\end{array}$ & $\begin{array}{l}\text { Christen, Pfaffermayr } \\
\text { and Wolfmayr (2019) }\end{array}$ & $\begin{array}{l}\text { Blank et } \\
\text { al. }(2018)\end{array}$ & $\begin{array}{c}\text { Simple } \\
\text { average }\end{array}$ \\
\hline Communication & 2.55 & 4.27 & - & 3.95 & 3.92 & 3.67 \\
\hline $\begin{array}{l}\text { Business } \\
\text { services }\end{array}$ & 2.18 & 4.02 & 1.57 & 3.77 & 4.51 & 3.21 \\
\hline $\begin{array}{l}\text { Financial } \\
\text { services }\end{array}$ & 1.6 & 4.18 & 1.59 & 2.05 & 3.27 & 2.54 \\
\hline Insurance & 2.2 & 4.18 & 1.59 & 2.59 & 3.27 & 2.77 \\
\hline Transport & 2.6 & 3.8 & 1.79 & 3.59 & 5.16 & 3.39 \\
\hline
\end{tabular}

Note: In the first column, the elasticity for communication is the simple average of telecommunications (2.7) and courier services (2.4); the elasticity for business services is the simple average of computer services (2.1), accounting and auditing (2.3), architecture and engineering (2.2) and legal services (2.1); the elasticity for transport is the simple average of air transport (1.9), maritime transport (2.8) and rail and road transport (3.1). In the second column, the elasticity for transport services is the simple average of inland transport (4.14), water transport (3.98) and air transport (3.29). In the third column, the elasticity for business services is the simple average of renting of machinery and equipment (1.312), computer and related activities (1.484) and R\&D and other business activities (1.976). In the fourth column, the elasticity for financial services is the simple average of financial services (1.51) and auxiliary financial (2.59). The estimates rely on firm-level data on profit margins from the United Kingdom and Finland (Rouzet, Benz and Spinelli, 2017), sector-level data on trade and unit labour costs from a set of 41 countries covered in the WIOD database (Egger et al., 2020), firm-level data on profit-margins from Austria (Christen, Pfaffermayr and Wolfmayr, 2019), firm-level data on profit-margins from Germany (Blank et al., 2018) and sector-level data on unit labour costs from a set of 59 economies covered in the OECD TiVA database (Fontagné, Orefice and Santoni, 2019).

\section{Simulation Results}

27. When translating this hypothetical scenario into relative changes in trade costs, three important determinants jointly shape the overall effect for each sector. Firstly, the effect is driven by the regulatory distance between the United States and the best performing country. As shown above, this distance is largest in the air transport sector, but it is also substantial in other sectors such as postal and courier services or maritime transport. Secondly, it is also shaped by the elasticity of substitution. Importantly, a smaller elasticity of substitution implies larger trade cost effects because larger changes in trade costs are required in order to achieve a given change in trade values. This can be seen in the case of commercial banking and insurance. By contrast, with higher elasticities of substitution domestic and foreign services are perceived more similar so that small changes in trade costs lead to substantial changes in trade values. Thirdly, trade cost effects are determined by the regression results reported above. The large coefficient obtained for commercial banking services (column 3, Table 1) stands out in this regard.

28. The results of this simulation reported in Table 3 suggest that the largest reduction of services trade costs can be expected in air transport, insurance, courier services and commercial banking. Expressed as percentages in the third column of Table 3, the magnitude of the trade cost reductions associated with the simulated changes in the regulatory barriers to cross-border services trade is limited in sectors where the US regulation is already very close to international best practice. For instance, the smallest reduction can be expected in rail transport, where the US already displays a relatively low STRI score.

29. The simulation reveals substantial potential for trade cost reductions in several sectors. The predicted reduction of the ad valorem equivalent in this scenario amounts to more than $20 \%$ in the case of the air transport sector, insurance, as well as courier services. Detailed information included in the STRI database can be used to identify potential starting points for further steps towards greater openness to trade in these sectors. In air transport services, US citizens must have control of at least $51 \%$ of non-voting equity and $75 \%$ of voting equity, while some OECD members allow domestic operations of fully foreign owned airlines. Some slots at airports are allocated on the basis of grandfathering and wet lease of foreign 
aircraft is prohibited. The insurance sector is regulated and supervised state-by-state. A domestic license and commercial presence is required in New York State for life and non-life insurance, while foreign reinsurance companies are required to post collateral in a local trust fund. Moreover, the majority of directors of insurance companies incorporated in New York must be citizens and residents of the United States. In the case of courier services, there is a monopoly for letters weighing less than 12.5 ounces and the major postal services provider in the country is controlled by the government.

30. The simulation similarly sheds light on significant scope for trade cost reductions in commercial banking and maritime transport. Regarding commercial banking, examples of barriers to trade include restrictive regulation concerning the ability of foreign banks, including US branches of foreign banks, to accept retail deposits from US citizens.

31. In maritime transport, companies owning vessels must be incorporated under the laws of the United States. In addition, the CEO, the chairman of the board of directors and a majority of directors must be U.S. citizens. At the same time, the cabotage market is not open to foreign firms. Under the Jones Act, merchandise transported by water between U.S. points must be carried by vessels built in the United States, carrying the U.S. flag, owned and manned by U.S. citizens.

\section{Table 4. Substantial reduction of services trade costs are possible}

\begin{tabular}{l|r|r|r|r}
\hline \multicolumn{1}{|c|}{ Sector } & $\begin{array}{c}\text { STRI } \\
\text { reduction }\end{array}$ & $\begin{array}{c}\text { Trade cost reduction } \\
\text { (in \%) }\end{array}$ & $\begin{array}{c}\text { 90\% confidence interval of trade cost } \\
\text { reduction (in \%) }\end{array}$ \\
\hline Computer services & -0.033 & -5.430 & -3.504 & -7.317 \\
\hline Legal services & -0.027 & -4.722 & -2.031 & -7.339 \\
\hline Accounting services & -0.031 & -5.328 & -2.296 & -8.265 \\
\hline Architecture services & -0.046 & -7.789 & -3.382 & -11.995 \\
\hline Engineering services & -0.046 & -7.798 & -3.386 & -12.008 \\
\hline Telecommunication & -0.024 & -3.950 & -2.542 & -5.338 \\
\hline Commercial banking & -0.038 & -16.499 & -10.889 & -21.755 \\
\hline Insurance & -0.092 & -22.913 & -16.334 & -28.975 \\
\hline Air transport & -0.181 & -23.502 & -12.948 & -32.777 \\
\hline Maritime transport & -0.103 & -14.122 & -7.578 & -20.203 \\
\hline Road freight transport & -0.021 & -3.096 & -1.614 & -4.555 \\
\hline Rail freight transport & -0.011 & -1.553 & -0.807 & -2.293 \\
\hline Courier services & -0.136 & -20.527 & -13.653 & -26.854 \\
\hline Logistics cargo-handling & -0.055 & -7.870 & -4.154 & -11.442 \\
\hline Logistics storage & -0.051 & -7.326 & -3.862 & -10.666 \\
\hline warehouse & & & & -9.539 \\
\hline Logistics freight forwarding & -0.046 & -6.539 & -3.440 & -9.788 \\
\hline Logistics customs brokerage & -0.047 & -6.713 & -3.533 & \\
\hline
\end{tabular}

Note: The shows reduction of the STRI and reduction of services trade costs in the United States. The scenario is based on the assumption of closing $50 \%$ of the gap between the current regime in the United States and the best performing country.

Source: Author's calculations based on STRI 2019 database, regression parameters summarised in Table 1 and mean elasticity of substitution reported in Table 2.

\section{Conclusion}

32. This paper describes a hypothetical scenario regarding the regulation of services in the United States. It evaluates the effect on services trade costs resulting from a liberalisation that manages to halve the gap between the current state of US services regulation and the international best performer among the group of OECD members. The average reduction in trade costs across the 17 sectors analysed would 
amount to 9.7 percentage points, with a quarter of the sectors experiencing reductions larger than 14.1 percentage points and another quarter experiencing reductions smaller than 5.3 percentage points.

33. In combination with the detailed regulatory information included in the STRI database, these results allow to identify sectors and policy areas where the potential for reductions of barriers to trade in services are higher and can inform policy makers about the potential economic implications of services liberalisation. Further work could encompass the use of macroeconomic or computable general equilibrium models to account for general equilibrium effects. 


\section{Annex A.}

\section{Sector Correspondence}

34. Cross-border services trade flows are recorded in the EBOPS (Extended Balance of Payments Services) classification. Codes from the first column are used to reference sectors throughout the rest of this document. Table A.1 reports the mapping of sectors from the different data sources. Table A.2 reports a detailed list of activities included in each sector, based on the ISIC rev. 4 classification.

\section{Table A.1. Sector correspondence}

\begin{tabular}{|c|c|c|c|c|c|}
\hline $\begin{array}{l}\text { STRI } \\
\text { code }\end{array}$ & Description & $\begin{array}{l}\text { Regression } \\
\text { code }\end{array}$ & Description & EBOPS 2010 & $\begin{array}{c}\text { ISIC } \\
\text { rev. } 4\end{array}$ \\
\hline CS & Computer services & \multirow[t]{5}{*}{ obs } & \multirow{5}{*}{$\begin{array}{l}\text { Business } \\
\text { Services }\end{array}$} & \multirow[t]{5}{*}{ SJ } & \multirow[t]{5}{*}{$69-82$} \\
\hline PSleg & Legal services & & & & \\
\hline PSacc & Accounting services & & & & \\
\hline PSarc & Architecture services & & & & \\
\hline PSeng & Engineering services & & & & \\
\hline TC & Telecommunication & \multirow[t]{2}{*}{$\mathrm{cmn}$} & \multirow[t]{2}{*}{ Communication } & \multirow[t]{2}{*}{ SI, SC4 } & \multirow{2}{*}{$\begin{array}{r}53+58- \\
63\end{array}$} \\
\hline CR & Courier services & & & & \\
\hline FSbnk & Commercial banking & ofi & $\begin{array}{r}\text { Financial } \\
\text { services }\end{array}$ & SG & $64+66^{*}$ \\
\hline FSins & Insurance & isr & Insurance & SF & $\begin{array}{l}65+ \\
66^{\star *}\end{array}$ \\
\hline TRair & Air transport & \multirow[t]{8}{*}{ otp } & \multirow[t]{8}{*}{ Transport } & \multirow{8}{*}{$\begin{array}{r}\text { SC12, SC2, SC3C } \\
\text { SC3B2, SC3G }\end{array}$} & \multirow[t]{8}{*}{ 49-52 } \\
\hline TRmar & Maritime transport & & & & \\
\hline TRrof & Road freight transport & & & & \\
\hline TRrai & Rail freight transport & & & & \\
\hline LScar & Logistics cargo-handling & & & & \\
\hline LSstg & $\begin{array}{r}\text { Logistics storage and } \\
\text { warehouse }\end{array}$ & & & & \\
\hline LSfgt & Logistics freight forwarding & & & & \\
\hline LScus & Logistics customs brokerage & & & & \\
\hline
\end{tabular}

Note: Transport includes water transport, air transport and transport not elsewhere classified. Not covered are electricity; gas manufacture, distribution; water; construction; trade; recreational and other services; public administration, defence, health, education; dwellings. ${ }^{*}$ Two thirds of ISIC66 (Activities auxiliary to financial service and insurance activities) is attributed to the sector ofi. ** One third of ISIC66 (Activities auxiliary to financial service and insurance activities) is attributed to the sector isr. 
Table A.2. Sector classification by reference to ISIC rev. 4

\begin{tabular}{|c|c|c|}
\hline GTAP & ISIC rev. 4 & Description \\
\hline obs & $\mathrm{M}, \mathrm{N}$ & Professional, scientific and technical activities and Administrative and support service activities \\
\hline \multirow[t]{7}{*}{$\mathrm{cmn}$} & 53 & Postal and courier activities \\
\hline & 58 & Publishing activities \\
\hline & 59 & Motion picture, video and television programme production, sound recording and music publishing activities \\
\hline & 60 & Programming and broadcasting activities \\
\hline & 61 & Telecommunications \\
\hline & 62 & Computer programming, consultancy and related activities \\
\hline & 63 & Information service activities \\
\hline \multirow[t]{3}{*}{ ofi } & 64 & Financial service activities, except insurance and pension funding \\
\hline & 661 & Activities auxiliary to financial service activities, except insurance and pension funding \\
\hline & 663 & Fund management activities \\
\hline \multirow[t]{2}{*}{ ins } & 65 & Insurance, reinsurance and pension funding, except compulsory social security \\
\hline & 662 & Activities auxiliary to insurance and pension funding \\
\hline \multirow[t]{4}{*}{ otp } & 49 & Land transport and transport via pipelines \\
\hline & 50 & Water transport \\
\hline & 51 & Air transport \\
\hline & 52 & Warehousing and support activities for transportation \\
\hline
\end{tabular}

\section{References}

Anderson, J. et al. (2015), Dark Costs, Missing Data: Shedding Some Light on Services Trade, The World Bank, http://dx.doi.org/10.1596/1813-9450-7465.

Anderson, J. and E. Van Wincoop (2003), "Gravity with Gravitas: A Solution to the Border Puzzle", American Economic Review, Vol. 93/1, pp. 170-192, http://dx.doi.org/10.1257/000282803321455214.

Andrenelli, A. et al. (2018), "Multinational production and trade in services", OECD Trade Policy Papers, No. 212, OECD Publishing, Paris, https://dx.doi.org/10.1787/16ec6b55-en.

Benz, S. (2017), "Services trade costs: Tariff equivalents of services trade restrictions using gravity estimation”, OECD Trade Policy Papers, No. 200, OECD Publishing, Paris, http://dx.doi.org/10.1787/dc607ce6-en.

Benz, S. and F. Gonzales (2019), "Intra-EEA STRI Database: Methodology and Results", OECD Trade Policy Papers, No. 223, OECD Publishing, Paris, https://dx.doi.org/10.1787/2aac6d21-en.

Benz, S. and A. Jaax (2020), "The costs of regulatory barriers to trade in services: New estimates of ad valorem tariff equivalents", OECD Trade Policy Papers, No. 238, OECD Publishing, Paris, https://doi.org/10.1787/bae97f98-en.

Blank, S. et al. (2018), "A structural quantitative analysis of services trade de-liberalization", Deutsche Bundesbank Discussion Paper No 47/2018.

Borchert, I., B. Gootiiz and A. Mattoo (2013), "Policy Barriers to International Trade in Services: Evidence from a New Database", The World Bank Economic Review, Vol. 28/1, pp. 162-188, http://dx.doi.org/10.1093/wber/lht017. 
Christen, E., M. Pfaffermayr and Y. Wolfmayr (2019), "Trade Costs in Services: Firm Survival, Firm Growth and Implied Changes in Employment", CESifo Working Papers No. 8008.

Dai, M., Y. Yotov and T. Zylkin (2014), "On the trade-diversion effects of free trade agreements", Economics Letters, Vol. 122/2, pp. 321-325, http://dx.doi.org/10.1016/j.econlet.2013.12.024.

Debaere, P., H. Görg and H. Raff (2013), "Greasing the wheels of international commerce: how services facilitate firms' international sourcing", Canadian Journal of Economics/Revue canadienne d'économique, Vol. 46/1, pp. 78-102, http://dx.doi.org/10.1111/caje.12006.

Dür, A., L. Baccini and M. Elsig (2014), "The design of international trade agreements: Introducing a new dataset", The Review of International Organizations, Vol. 9/3, pp. 353-375, http://dx.doi.org/10.1007/s11558-013-9179-8.

Eaton, J. and Kortum, S. (2018), Trade in Goods and Trade in Services. Ing, L.Y.; Yu, M. (eds.): World Trade Evolution: Growth, Productivity, and Employment, Routledge.

Egger, P. et al. (2020), "Measurement, Aggregation and Decomposition".

Findlay, C. and T. Warren (eds.) (1990), Impediments to Trade in Services: Measurement and Policy Implications, Routledge.

Fontagné, L., G. Orefice and G. Santoni (2019), Services Trade Elasticity.

Geloso Grosso, M. et al. (2015), "Services Trade Restrictiveness Index (STRI): Scoring and Weighting Methodology”, OECD Trade Policy Papers, No. 177, OECD Publishing, Paris, https://dx.doi.org/10.1787/5js7n8wbtk9r-en.

Görg, H. and L. Jabbour (2016), "Availability of Business Services and Outward Investment: Evidence from French Firms", Review of International Economics, Vol. 24/4, pp. 797-819

Heid, B., M. Larch and Y. Yotov (2015), A Simple Method to Estimat the Effects of NonDiscriminatory Trade Policy Within Structural Gravity Models, http://www.etsg.org/ETSG2015/Papers/439.pdf.

Lamprecht, P. and S. Miroudot (2018), "The value of market access and national treatment commitments in services trade agreements", OECD Trade Policy Papers, No. 213, OECD Publishing, Paris, https://dx.doi.org/10.1787/d8bfc8d8-en.

Miroudot, S. and C. Cadestin (2017), "Services In Global Value Chains: From Inputs to ValueCreating Activities", OECD Trade Policy Papers, No. 197, OECD Publishing, Paris, https://dx.doi.org/10.1787/465f0d8b-en.

Nordås, H. and D. Rouzet (2017), "The Impact of Services Trade Restrictiveness on Trade Flows", World Economy, Vol. 40/6, http://dx.doi.org/10.1111/twec.12424.

Rouzet, D., S. Benz and F. Spinelli (2017), "Trading firms and trading costs in services: Firm-level analysis", OECD Trade Policy Papers, No. 210, OECD Publishing, Paris, http://dx.doi.org/10.1787/b1c1a0e9-en.

Santos Silva, J. and S. Tenreyro (2006), "The Log of Gravity", Review of Economics and Statistics, 
Vol. 88/4, pp. 641-658, https://doi.org/10.1162/rest.88.4.641.

United Nations (2012), Manual on Statistics of International Trade in Services 2010, United Nations.

Van der Marel, E. and B. Shepherd (2013), "Services trade, regulation and regional integration:

Evidence from sectoral data", World Economy, Vol. 36/11, pp. 1393-1405,

http://dx.doi.org/10.1111/twec.12083.

Yotov, Y. (2012), "A simple solution to the distance puzzle in international trade", Economics Letters, Vol. 117/3, pp. 794-798, http://dx.doi.org/10.1016/j.econlet.2012.08.032.

Yotov, Y. et al. (2016), An Advanced Guide to Trade Policy Analysis: The Structural Gravity Model, World Trade Organization. 